\title{
EKSPERIMENTASI MODEL PEMBELAJARAN KOOPERATIF TIPE TEAM ASSISTED INDIVIDUALIZATION (TAI) DAN TEAMS GAMES TOURNAMENT (TGT) PADA MATERI PERSAMAAN DAN PERTIDAKSAMAAN DITINJAU DARI GAYA BELAJAR SISWA KELAS X SMK SE- KABUPATEN NGAWI TAHUN PELAJARAN 2015/2016
}

\author{
Lia Septy Nirawati ${ }^{1}$, Tri Atmojo Kusmayadi ${ }^{2}$, Imam Sujadi ${ }^{3}$ \\ 1,2,3 Prodi Magister Pendidikan Matematika, FKIP Universitas Sebelas Maret Surakarta
}

\begin{abstract}
The purpose of this study was to know the effect of the learning models on the learning achievement in mathematics viewed from the students adversity quotient. The learning models compared were the cooperative learning of TAI, TGT, and direct learning model. The type of research was a quasi-experimental research with a $3 \times 3$ factorial design. The study population was all grade 10 students of Secondary Schools in Ngawi Regency in the academic year of 2015/2016. Instruments used for data collection were mathematics achievement test and learning style questionnaire. The data analysis technique used was the two-way ANOVA with unequal cell. Based on the hypothesis test, it was concluded that: 1) The mathematics learning achievement of the students who were treated by TAI learning model was better than the mathematics learning achievement of the students who were treated by TGT and direct learning model on equality and inequality, the mathematics learning achievement of the students who were treated by TGT learning model was better than the mathematics learning achievement of the students who were treated by direct learning model on equality an inequality; 2) The mathematics learning achievement of the students with visual type was better than the mathematics learning achievement of the students with auditory or kinesthetic type and the learning achievement of auditory type students was better than the learning achievement of kinesthetic type students on equality and inequality; 3) The visual type students who were treated by TAI learning model had better mathematics learning achievement than the students with TGT or direct learning model and the students mathematics learning learning achievement with TGT learning model was same the students with direct learning model; the mathematics achievement of auditory type students who were treated by TAI learning model had better mathematics learning achievement than the students with TGT or direct learning model and students who were treated by TGT learning model had better mathematics learning achievement than the students with direct learning model; the mathematics achievement of kinesthetic type students who were treated by TAI, TGT, and direct learning models had the same mathematics learning achievement; 4) In TAI, TGT and direct learning model, the mathematics learning achievement of visual type, auditory, and kinesthetic had the same mathematics learning achievement.
\end{abstract}

Keywords: TAI, TGT, Direct Learning Model, Learning Style, Mathematics Learning Achievement

\section{PENDAHULUAN}

Matematika merupakan ilmu universal yang mendasari perkembangan teknologi modern mempunyai peranan penting di berbagai disiplin ilmu dalam mengembangkan daya pikir manusia. Oleh karena itu, matematika diberikan mulai dari sekolah dasar untuk membekali siswa dengan kemampuan berpikir logis, sistematis, kritis, kreatif dan kemampuan bekerja sama. 
Supartono dalam Misdalina, $d k k$. (2009: 54) menyatakan bahwa kenyataan yang masih sering ditemui adalah masih banyak siswa yang mengalami kesulitan dalam mempelajari matematika. Hal ini terlihat pada nilai ujian nasioanal tahun pelajaran 2014/2015 yang menunjukkan bahwa rata-rata nilai matematika SMK di tingkat kabupaten adalah 4,66, provinsi 5,12 dan nasional 5,10. Nilai rata-rata matematika SMK di tingkat kabupaten masih rendah dibandingkan tingkat provinsi maupun nasional. Abdussakir (2009) menyatakan bahwa pada tingkat SMK masih banyak siswa yang belum memahami konsep persamaan dan pertidaksamaan. Hal ini sejalan dengan hasil penelitian Sunardi (2001) yang menyatakan bahwa masih banyak siswa yang salah dalam menyelesaikan soal-soal mengenai materi persamaan dan pertidaksamaan. Tampak pada daya serap kemampuan siswa SMK di Kabupaten Ngawi dalam memecahkan masalah yang berkaitan dengan sistem persamaan dan pertidaksamaan serta dapat menerapkannya dalam bidang kejuruan di tingkat kabupaten yaitu 43,76\%, di tingkat provinsi 54,60\%, dan di tingkat nasional 52,89\% (PAMER, 2014).

Berdasarkan wawancara pada beberapa guru matematika SMK di Kabupaten Ngawi diperoleh kesimpulan penyebab kesulitan siswa dalam memahami persamaan dan pertidaksamaan antara lain. (1) Rumus-rumus di sekolah hanya diberikan saja secara langsung dan dihafal, tanpa proses penemuan sendiri, sehingga pelajaran tersebut diduga tidak bermakna dan menyulitkan siswa untuk memahami dan mengingat rumus-rumus tersebut; (2) Proses pembelajaran yang dilakukan selama ini oleh guru masih menggunakan metode ceramah yang membuat siswa menjadi pasif.

Guru sebaiknya mencari solusi pembelajaran yang efektif, hal ini seperti diungkapkan oleh Tran (2013: 5) yang menyatakan bahwa salah satu tujuan utama guru di sekolah agar secara efektif menggunakan strategi pembelajaran untuk dapat meningkatkan kemampuan kognitif dan afektif siswa. Menurut Suyitno (2004: 2), pembelajaran matematika adalah suatu proses atau kegiatan guru dalam mengajarkan matematika kepada para siswanya, yang di dalamnya terkandung upaya guru untuk menciptakan iklim dan pelayanan terhadap kemampuan, potensi, minat, bakat, dan kebutuhan siswa tentang matematika yang amat beragam, agar terjadi interaksi yang optimal antara guru dengan siswa, siswa dengan siswa lainnya dalam mempelajari matematika.

Penerapan model pembelajaran kooperatif merupakan salah satu cara untuk mengatasi permasalahan tersebut. Pembelajaran kooperatif didasarkan pada keyakinan bahwa pembelajaan yang paling efektif bila siswa terlibat dalam berbagi ide dan bekerja sama untuk menyelesaikan tugas-tugas akademik (Zakaria dan Iksan, 2007: 36), sehingga dapat dikatakan bahwa pembelajaran kooperatif bernaung dalam teori konstruktivis 
(Trianto, 2012: 56). Menurut Slavin (2005: 4-5) "penggunaan pembelajaran kooperatif dapat meningkatkan prestasi para siswa dan dapat mengembangkan hubungan antar kelompok penerimaan terhadap teman sekelas yang lemah dalam bidang akademik, dan meningkatkan rasa harga diri”. Dari beberapa pendapat tersebut maka penelitian ini menerapkan model pembelajaran kooperatif dalam pembelajaran matematika di kelas.

Di dalam penelitian ini, peneliti menggunakan model pembelajaran kooperatif tipe TAI dan TGT. Pemilihan model pembelajaran ini dirasa cocok untuk digunakan pada materi persamaan dan pertidaksamaan, karena pada model pembelajaran kooperatif tipe TAI, siswa diminta untuk menyelesikan masalah secara berkelompok. Sedangkan pada model pembelajaran kooperatif tipe TGT, siswa diminta untuk menyelesaikan masalah secara berkelompok dan kemudian menyelesaikan masalah dalam games pada turnamen secara individu dan hasil turnamen akan mempengaruhi nilai kelompok. Selain itu, pemilihan model pembelajaran kooperatif tipe ini juga didasarkan pada penelitian yang dilakukan oleh Lilia (2014) dalam penelitiannya memberikan hasil yaitu model pembelajaran kooperatif tipe TAI memberikan prestasi belajar yang lebih baik daripada model pembelajaran kooperatif tipe TGT dan langsung, TGT lebih baik daripada langsung. Penelitian terdahulu ada juga yang menyatakan bahwa model pembelajaran kooperatif tipe TAI memberikan prestasi yang lebih baik dari model pembelajaran kooperatif tipe yang lain.

Selain model pembelajaran, guru juga sebaiknya memperhatikan gaya belajar siswa. Gaya belajar merupakan cara yang konsisten yang dilakukan oleh seorang siswa dalam menangkap stimulus atau informasi, cara mengingat, berpikir, dan memecahkan masalah. Berdasarkan pada hal tersebut, diduga gaya belajar yang dimiliki masing-masing siswa juga berpengaruh terhadap prestasi belajar siswa.

Tujuan penelitian ini adalah untuk mengetahui: 1) manakah yang menghasilkan prestasi belajar matematika lebih baik antara model pembelajaran TAI, TGT atau modelpembelajaran langsung, 2) manakah yang mempunyai prestasi belajar matematika lebih baik antara siswa dengan gaya belajar tipe visual, auditorial, atau kinestetik, 3) manakah yang menghasilkan prestasi belajar yang lebih baik pada masing-masing tipe gaya belajar, model pembelajaran TAI, TGT, atau model pembelajaran langsung, 4) manakah yang menghasilkan prestasi belajar yang lebih baik pada masing-masing model pembelajaran, siswa tipe visual, auditorial, atau kinestetik. 


\section{METODE PENELITIAN}

Penelitian ini dilaksanakan di SMK Se-Kabupaten Ngawi pada semester ganjil tahun pelajaran 2015/2016. Jenis penelitian ini adalah penelitian eksperimental semu (quasi experimental research) dengan rancangan factorial $3 \times 3$. Populasi dalam penelitian ini adalah siswa SMK Kelas X semester ganjil tahun pelajaran 2015/2016. Teknik sampling dalam penelitian ini adalah stratified cluster random sampling sehingga terpilih sampel sebagai kelompok tinggi yaitu siswa kelas AK1, AK1, TKR SMK Negeri 1 Gerih, kelompok sedang yaitu siswa kelas AK1, AK2, TN SMK PGRI 4 Ngawi, dan kelompok rendah yaitu siswa kelas AK1, AK2, TKJ SMK PGRI 6 Ngawi.

Dalam penelitian ini terdapat dua variabel bebas yaitu model pembelajaran dan gaya belajar siswa dan satu variabel terikat yaitu prestasi belajar matematika. Metode pengumpulan data meliputi metode dokumentasi yang digunakan untuk memperoleh data banyak sekolah dan siswa dalam populasi, metode angket digunakan untuk memperoleh data tentang gaya belajar siswa, sedangkan metode tes digunakan untuk memperoleh data prestasi belajar siswa pada materi persamaan dan pertidaksamaan. Data kemampuan awal prestasi belajar matematika siswa diperoleh dari nilai UN kelas IX tahun 2014/2015 dari kelas eksperimen. Sebelum melakukan eksperimen, dilakukan uji normalitas, homogenitas dan uji keseimbangan terhadap data kemampuan awal matematika menggunakan anava satu jalan dengan sel tak sama, sedangkan untuk data prestasi belajar matematika dianalisis menggunakan analisis variansi dua jalan dengan sel tak sama setelah dilakukan uji normalitas dan homogenitas terlebih dahulu. Uji normalitas untuk data kemampuan awal dan data prestasi belajar dilakukan menggunakan metode Lilliefors dan uji homogenitas variansi populasi menggunakan metode Bartlett. Uji hipotesis menggunakan analisis variansi dua jalan dengan sel tak sama. Uji lanjut pasca anava menggunakan metode Scheffe, apabila hasil analisis variansi menunjukkan bahwa hipotesis nol ditolak.

\section{HASIL PENELITIAN DAN PEMBAHASAN}

Hasil uji prasyarat menyimpulkan bahwa semua sampel berasal dari populasi yang berdistribusi normal dan mempunyai variansi yang sama. Uji keseimbangan dilakukan terhadap data kemampuan awal dengan tujuan untuk mengetahui apakah populasi siswa yang dikenai model pembelajaran TAI, TGT, dan langsung mempunyai kemampuan awal yang sama. Berdasarkan hasil uji keseimbangan disimpulkan bahwa sampel dari populasi siswa yang dikenai model pembelajaran TAI, TGT, dan langsung dalam keadaan seimbang. 
Selanjutnya dilakukan uji hipotesis menggunakan anava dua jalan dengan sel tak sama. Rangkuman anava dua jalan dengan sel tak sama disajikan pada Tabel 1 sebagai berikut.

Tabel 1 Rangkuman Analisis Variansi Dua Jalan dengan Sel Tak Sama

\begin{tabular}{ccccccc}
\hline Sumber & & & & & \multicolumn{2}{c}{ Keputusan Uji } \\
\hline Model (A) & 15108,8402 & 2 & 7554,4201 & 57,2890 & 3,00 & HO ditolak \\
\hline Gaya Belajar(B) & 840,9132 & 2 & 420,4566 & 3,1885 & 3,00 & HO ditolak \\
\hline Interaksi (AB) & 1693,8577 & 4 & 423,4644 & 3,2113 & 2,37 & HO ditolak \\
\hline Galat & 43119,8537 & 327 & 131,8650 & - & - & - \\
\hline Total & 60763,4648 & 335 & - & - & - & -
\end{tabular}

Berdasarkan Tabel 1, dapat diperoleh bahwa: (1) terdapat perbedaan prestasi belajar matematika antara siswa yang mendapatkan model pembelajaran TAI, TGT, dan langsung, (2) terdapat perbedaan prestasi belajar matematika antara siswa tipe visual, auditorial, dan kinestetik, (3) terdapat interaksi antara model pembelajaran dan gaya belajar siswa terhadap prestasi belajar matematika siswa.

Rangkuman rerata marginal pada masing-masing model pembelajaran dan gaya belajar dapat dilihat pada Tabel 2 berikut.

Tabel 2 Rerata Marginal dari Model Pembelajaran dan Gaya Belajar

\begin{tabular}{lllll}
\hline Model Pembelajaran & \multicolumn{3}{c}{ Gaya Belajar } & Rerata Marginal \\
\cline { 2 - 4 } & Visual & Auditorial & Kinestetik & \\
\hline TAI & 70,0377 & 70,1905 & 63,4286 & 69,2477 \\
\hline TGT & 57,7647 & 58,2545 & 54,8800 & 57,3684 \\
\hline Langsung & 54,1538 & 44,9474 & 51,2653 & 49,8053 \\
\hline Rerata Marginal & 62,6903 & 58,2222 & 54,2273 & \\
\hline
\end{tabular}

Berdasarkan hasil perhitungan anava diperoleh bahwa $H_{O A}$ ditolak. Oleh karena itu, perlu dilakukan uji komparasi rerata antar baris. Rangkuman hasil uji komparasi ganda antar baris disajikan dalam Tabel 3 berikut ini:

Tabel 3 Rangkuman Hasil Uji Komparasi Ganda Antar Baris

\begin{tabular}{llll}
\hline No & & & Keputusan Uji \\
\hline 1 & 59,6318 & 6,00 & $H_{0}$ ditolak \\
\hline 2 & 159,0457 & 6,00 & $H_{0}$ ditolak \\
\hline 3 & 24,6166 & 6,00 & $H_{0}$ ditolak \\
\hline
\end{tabular}

Berdasarkan Tabel 3 dan rerata marginal pada Tabel 2, dapat diperoleh bahwa model pembelajaran TAI menghasilkan prestasi belajar yang lebih baik daripada model pembelajaran TGT dan model pembelajaran langsung. Model pembelajaran TGT menghasilkan prestasi belajar yang lebih baik daripada model pembelajaran langsung. Hal ini sekaligus melengkapi penelitian yang dilakukan oleh Setyansah (2012) yang 
masing-masing mengatakan bahwa model pembelajaran kooperatif tipe TAI lebih baik daripada model pembelajaran kooperatif tipe GI dan konvensional. Zakaria dan Iksan (2007) mengatakan bahwa pembelajaran kooperatif lebih efektif daripada model pembelajaran tradisional. Rusmawati et al. (2013) mengatakan bahwa terdapat perbedaan prestasi yang dihasilkan dan menunjukkan bahwa model pembelajaran kooperatif tipe TGT lebih unggul daripada model pembelajaran langsung.

Berdasarkan hasil perhitungan anava diperoleh bahawa $H_{0 B}$ ditolak. Oleh karena itu, perlu dilakukan uji komparasi ganda antar kolom. Rangkuman hasil uji komparasi rerata antar kolom disajikan dalam Tabel 4 berikut ini:

\section{Tabel 4 Rangkuman Hasil Uji Komparasi Ganda Antar Kolom}

\begin{tabular}{llll}
\hline No & & & Keputusan Uji \\
\hline 1 & 9,3125 & 6,00 & $H_{0}$ ditolak \\
\hline 2 & 26,8710 & 6,00 & $H_{0}$ ditolak \\
\hline 3 & 6,4477 & 6,00 & $H_{0}$ ditolak \\
\hline
\end{tabular}

Berdasarkan Tabel 4 dan rerata marginal pada Tabel 2, dapat diperoleh bahwa siswa tipe visual mempunyai prestasi belajar yang lebih baik daripada siswa tipe auditorial dan kinestetik. Siswa kategori auditorial mempunyai prestasi belajar yang lebih baik daripada siswa kategori kinestetik. Hal ini juga sejalan dengan hasil penelitian Wahyu Utomo tahun 2014 menyatakan bahwa untuk semua model pembelajaran (TAI, TGT, dan langsung), siswa dengan gaya belajar visual memiliki prestasi belajar matematika lebih baik daripada siswa dengan gaya belajar auditorial dan kinestetik, siswa dengan gaya belajar auditorial memiliki prestasi belajar matematika yang lebih baik daripada siswa dengan gaya belajar kinestetik. Berdasarkan hasil perhitungan anava diperoleh bahwa $H_{O A B}$ ditolak. Oleh karena itu, perlu dilakukan uji komparasi rerata antar sel pada baris dan kolom yang sama.

Berdasarkan hasil uji komparasi rerata antar sel pada kolom yang sama disajikan dalam Tabel 5.

Tabel 5 Hasil Uji Komparasi Ganda Antar Sel pada Kolom yang Sama

\begin{tabular}{llll}
\hline No. & & & \multicolumn{1}{c}{ Keputusan Uji } \\
\hline 1 & 23,6597 & 15,52 & $H_{0}$ ditolak \\
\hline 2 & 33,3739 & 15,52 & $H_{0}$ ditolak \\
\hline 3 & 1,4568 & 15,52 & $H_{0}$ diterima \\
\hline 4 & 25,7290 & 15,52 & $H_{0}$ ditolak \\
\hline 5 & 96,4049 & 15,52 & $H_{0}$ ditolak \\
\hline 6 & 30,1791 & 15,52 & $H_{0}$ ditolak \\
\hline 7 & 4,9735 & 15,52 & $H_{0}$ diterima \\
\hline 8 & 12,2167 & 15,52 & $H_{0}$ diterima \\
\hline 9 & 1,6403 & 15,52 & $H_{0}$ diterima \\
\hline
\end{tabular}


Berdasarkan Tabel 5 dan rerata pada Tabel 2, dapat diperoleh bahwa pada siswa tipe visual yang mendapatkan model pembelajaran TAI, lebih baik daripada siswa yang mendapatkan pembelajaran TGT maupun langsung dan prestasi belajar matematika siswa yang mendapatkan model pembelajaran TGT sama dengan siswa yang mendapatkan model pembelajaran langsung. Kesimpulan tersebut tidak sesuai dengan hipotesis penelitian karena siswa yang mempunyai gaya belajar visual cenderung mampu memecahkan masalah dengan cepat dan tepat terutama pada materi yang menyangkut persamaan maupun pertidaksamaan serta lebih mudah memahami materi yang dipelajari meskipun siswa dituntut untuk belajar mandiri maupun hanya sedikit mendengarkan penjelasan dari guru. Siswa dengan gaya belajar visual akan tertarik jika dalam pembelajaran diberikan banyak diberikan latihan-latihan soal karena pada dasarnya siswa dengan gaya belajar visual mempunyai karakteristik rasa ingin tahu yang luas dan mendalam. Siswa dengan gaya belajar visual juga mempunyai pemahaman yang lebih dan cepat saat diberikan banyak latihan soal dan mereka cenderung lebih cepat mengerti. Hal ini dimungkinkan pada model pembelajaran kooperatif tipe TAI menghasilkan prestasi yang lebih baik daripada model pembelajaran yang lain, karena model pembelajaran kooperatif tipe TAI banyak memberikan tugas-tugas atau latihan-latihan soal kepada siswa tipe auditorial, siswa yang mendapatkan model pembelajaran TAI memiliki prestasi belajar matematika yang lebih baik daripada siswa yang mendapatkan model pembelajaran TGT maupun langsung san siswa yang mendapatkan model pembelajaran TGT lebih baik daripada siswa yang mendapatkan model pembelajaran langsung. Hal ini sesuai dengan hipotesis penelitian, karena siswa dengan gaya belajar auditorial dapat memahami, cukup cepat mengerti serta dapat memecahkan masalah mengenai materi yang dipelajari terutama pada materi persamaan maupun pertidaksamaan. Siswa dengan gaya belajar auditorial juga dapat ikut serta dalam pembelajaran yang mandiri maupun kelompok. Siswa dengan gaya belajar auditorial cenderung lebih tertarik pada pembelajaran yang menuntut siswa untuk lebih aktif serta mereka tidak akan kesulitan jika dituntut untuk belajar secara kelompok dan diberi banyak latihan soal karena siswa dengan gaya belajar auditorial lebih mudah untuk beradapatasi. Sehingga, dimungkinkan model pembelajaran kooperatif tipe TAI dan TGT akan cenderung lebih cocok untuk siswa dengan gaya belajar auditorial karena pada kedua model tersebut siswa belajar secara kelompok dan siswa dituntut untuk lebih aktif dalam pembelajaran.

Berdasarkan Tabel 5 dan rerata pada Tabel 2, dapat disimpulkan bahwa pada siswa tipe kinestetik, siswa yang mendapatkan model pembelajaran TAI, TGT, dan 
langsung mempunyai prestasi belajar matematika yang sama. Hal ini sesuai hipotesis penelitian krena siswa yang mempunyai gaya belajar kinestetik akan merasa sulit dalam memahami materi khususnya materi persamaan dan pertidaksamaan karena pada materi persamaan dan pertidaksamaan lebih banyak disajikan dalam bentuk soal cerita serta akan sulit dalam pembelajaran kelompok maupun mandiri karena pada dasarnya kemampuan memahami dan mengerti memang sulit bagi siswa tersebut. Seperti yang sudah dijelaskan sebelumnya bahwa model pembelajaran kooperatif tipe TAI dan TGT menuntut siswa untuk lebih aktif dalam pembelajaran dan siswa belajar secara kelompok, tetapi pada model pembelajaran langsung siswa cenderung pasif karena pembelajaran berpusat pada guru.

Rangkuman hasil uji komparasi rerata antar sel pada baris yang sama disajikan dalam Tabel 6 berikut ini:

Tabel 6 Hasil Uji Komparasi Ganda antar Sel pada Baris yang Sama

\begin{tabular}{llll}
\hline No. & & & Keputusan Uji \\
\hline 1 & 0,0041 & 15,52 & $H_{0}$ diterima \\
\hline 2 & 3,6685 & 15,52 & $H_{0}$ diterima \\
\hline 3 & 3,6408 & 15,52 & $H_{0}$ diterima \\
\hline 4 & 0,0382 & 15,52 & $H_{0}$ diterima \\
\hline 5 & 0,9092 & 15,52 & $H_{0}$ diterima \\
\hline 6 & 1,4843 & 15,52 & $H_{0}$ diterima \\
\hline 7 & 9,9228 & 15,52 & $H_{0}$ diterima \\
\hline 8 & 1,0748 & 15,52 & $H_{0}$ diterima \\
\hline 9 & 6,4786 & 15,52 & $H_{0}$ diterima \\
\hline
\end{tabular}

Berdasarkan Tabel 6 dan rerata pada Tabel 2, dapat disimpulkan bahwa pada model pembelajaran TAI, prestasi belajar matematika siswa tipe visual, auditorial, dan kinestetik mempunyai prestasi belajar yang sama. Hipotesis tersebut tidak terpenuhi karena pada pembelajaran menggunakan model pembelajaran TAI siswa kategori auditorial akan cenderung mengambil langkah positif terlebih dahulu dalam menghadapi masalah misalnya, mereka akan mencoba menyelesaikannya, walaupun nantinya akan menyerah jika mendapatkan permasalahan yang rumit. Dalam kegiatan pembelajaran model TAI, siswa kategori auditorial cenderung belum dapat membangun rasa nyaman dan kurang bersemangat mencoba soal-soal latihan yang diberikan baik secara individu maupun pada saat diskusi kelompok sehingga kesulitan dalam mengkonstruksikan pengetahuannya. Hal tersebut bisa membuat prestasi belajar matematika siswa kategori auditorial menurun. Dengan demikian, pada model pembelajaran TAI, siswa kategori auditorial menghasilkan prestasi belajar yang sama dengan siswa kategori kinestetik.

Berdasarkan Tabel 6 dan rerata pada Tabel 2, dapat disimpulkan bahwa pada model pembelajaran TGT, prestasi belajar matematika siswa tipe visual, auditorial, dan 
kinestetik mempunyai prestasi belajar yang sama. Hal ini tidak sesuai hipotesis penelitian karena pada model pembelajaran TGT siswa tipe visual cenderung berusaha sangat keras untuk dapat menyelesaikan tugasnya walaupun nantinya di tengah jalan menemukan kesulitan dalam mengerjakan soal. Siswa dalam kategori ini akan berusaha menjadikan dirinya mampu mengerjakan tugas yang diberikan. Pada model pembelajaran TGT siswa tipe auditorial cenderung mengambil langkah positif terlebih dahulu, dalam menghadapi masalah misalnya, mereka akan mencoba menyelesaikannya, walaupun nantinya akan menyerah jika mendapatkan permasalahan yang rumit. Dalam proses pembelajarannya siswa kategori ini dapat mengidentifikasi masalah yang relevan dengan permasalahan yang dihadapinya, dan dapat menyelesaikan permasalahan tersebut. Sedangkan pada siswa tipe kinestetik cenderung berhenti atau menolak suatu ketika mereka dihadapkan dalam permasalahan. Mereka akan lebih memilih melakukan kegiatan lainnya yang sekiranya tidak memberatkan dirinya. Dengan demikian, pada pembelajaran TTW, siswa tipe visual memiliki prestasi belajar yang sama dengan siswa tipe kinestetik.

Berdasarkan Tabel 6 dan rerata pada Tabel 2, dapat disimpulkan bahwa pada model pembelajaran langsung, prestasi belajar matematika siswa tipe visual, auditorial, dan kinestetik mempunyai prestasi belajar yang sama. Hipotesis tersebut tidak terpenuhi karena siswa tipe auditorial pada proses pembelajaran langsung cenderung mudah menyerah pada saat diskusi kelas untuk menyelesaikan masalah. Begitu juga siswa kategori kinestetik walaupun sudah mau mencoba untuk menyelesaikan masalah namun belum bisa membangun rasa nyaman dalam diskusi kelas, sehingga mereka sangat memerlukan bimbingan dari teman sebaya dalam diskusi kelompok. Dengan demikian prestasi belajar matematika siswa pada pembelajaran langsung, siswa kategori auditorial sama dengan siswa kategori kinestetik.

\section{SIMPULAN DAN SARAN}

Berdasarkan analisis data dan pembahasan, diperoleh kesimpulan sebagai berikut. 1) Model pembelajaran kooperatif tipe TAI memberikan prestasi belajar yang lebih baik daripada model pembelajaran kooperatif tipe TGT maupun model pembelajaran langsung. Model pembelajaran kooperatif tipe TGT memberikan prestasi belajar yang lebih baik daripada model pembelajaran langsung. 2) Siswa dengan gaya belajar visual mempunyai prestasi belajar yang lebih baik daripada siswa dengan gaya belajar auditorial maupun siswa dengan gaya belajar kinestetik. Siswa dengan gaya belajar auditorial mempunyai prestasi belajar yang lebih baik daripada siswa dengan gaya belajar kinestetik. 3) Pada siswa dengan gaya belajar visual, model pembelajaran kooperatif tipe TAI memberikan 
prestasi belajar yang lebih baik daripada model pembelajaran kooperatif tipe TGT maupun model pembelajaran langsung tetapi model pembelajaran kooperatif tipe TGT memberikan prestasi belajar yang sama dengan model pembelajaran langsung. Pada siswa dengan gaya belajar auditorial, model pembelajaran kooperatif tipe TAI memberikan prestasi belajar yang lebih baik daripada model pembelajaran kooperatif tipe TGT maupun model pembelajaran langsung serta model pembelajaran kooperatif tipe TGT memberikan prestasi belajar yang lebih baik daripada model pembelajaran langsung. Pada siswa dengan gaya belajar kinestetik, model pembelajaran kooperatif tipe TAI, model pembelajaran kooperatif tipe TGT maupun model pembelajaran langsung memberikan prestasi belajar yang sama. 4) Pada model pembelajaran kooperatif tipe TAI, siswa dengan gaya belajar visual, siswa dengan gaya belajar auditorial dan siswa dengan gaya belajar kinestetik mempunyai prestasi belajar yang sama. Pada model pembelajaran koperatif tipe TGT, siswa dengan gaya belajar visual, siswa dengan gaya belajar auditorial dan siswa dengan gaya belajar kinestetik mempunyai prestasi belajar yang sama. Pada model pembelajaran langsung, siswa dengan gaya belajar visual, siswa dengan gaya belajar auditorial dan siswa dengan gaya belajar kinestetik mempunyai prestasi belajar yang sama.

Berdasarkan simpulan hasil penelitian di atas, dapat diberikan beberapa saran sebagai berikut. Mengacu pada hasil penelitian yang menunjukkan bahwa model pembelajaran TAI menghasilkan prestasi belajar yang lebih baik dibandingkan model pembelajaran TGT dan model pembelajaran langsung, maka disarankan kepada guru mata pelajaran matematika untuk menggunakan model pembelajaran TAI, karena dengan model tersebut siswa mampu terlibat aktif berdiskusi, dan memecahkan masalah matematika dalam kegiatan kelompok serta mampu menyelesaikan latihan-latihan soal yang diberikan. Hal tersebut mampu meningkatkan prestasi belajar matematika siswa. Sesuai dengan hasil penelitian ini yang menunjukkan bahwa masing-masing kategori gaya belajar siswa memberikan pengaruh terhadap prestasi belajar matematika, guru diharapkan untuk mengetahui gaya belajar siswa. Sehingga guru dapat memilih model pembelajaran yang sesuai dengan karakteristik yang dimiliki siswa. Hendaknya guru memperhatikan keberagaman siswa dalam pembagian kelompok belajar, agar dalam setiap kelompok tersebut terdapat siswa dengan tipe visual yang dapat dijadikan sebagai tutor sebaya, supaya nantinya setiap kelompok dapat mengikuti proses pembelajaran dengan maksimal. 


\section{DAFTAR PUSTAKA}

Abdussakir. 2009. Pembelajaran Geometri Sesuai Teori Van Hiele. Jurnal Kependidikan dan Keagamaan, 7(2): 1499-1693. Tersedia di http://abdussakir.wordpress.com/2011/02/09/pembelajaran-geometri- lengkap/ [diakses 13-05-2015].

Goos, M. 2004. Learning Mathematics in a Classroom Community of Inquiry.Journal of Research of Mathematics Education, Vol. 35, no. 4: 258-291.

Misdalina, Zulkardi dan Purwoko. 2009. Pengembangan Materi Integral untuk Sekolah Menengah Atas (SMA) Menggunakan Pendekatan Pendidikan Matematika Realistik Indonesia (PMRI) di Palembang. Jurnal Pendidikan Matematika: 3 (1):61-74.

Setyansah, R.K. 2012. Efektivitas Pembelajaran Kooperatif Tipe TAI (Team Assisted Individualization) dan GI (Group Investigation) Pada Materi Persamaan Garis Lurus Ditinjau Dari Konsep Diri Siswa Kelas VIII SMP Negeri se-Kota Madiun. Tesis tidak dipublikasikan. Surakarta: UNS.

Slavin, R.E. 2005. Cooperative Learning. Bandung: Nusa Media.

Suprapto. 2012. Eksperimentasi Model Pembelajaran Kooperatif Tipe Teams Games Tournamens (TGT) dan Numbered Head Together (NHT) Pada Materi Geometri dan Pengukuran Ditinjau dari Gaya Belajar Siswa SMP Negeri di Kabupaten Bojonegoro Tahun Pelajaran 2011/2012. Tesis tidak dipublikasikan. Surakarta: UNS.

Suyitno, A. 2004. Dasar-dasar dan Proses Pembelajaran Matematika 1. Semarang: Universitas Negeri Semarang.

Trianto. 2012. Mendesain Model Pembelajaran Inovatif-Progresif. Jakarta: Kencana Perdana Media Group.

Wuryanto. 2011. Pengaruh Model Pembelajaran Kooperatif tipe Student TeamsAchievement Division (STAD) dan tipe Team-Assisted Individualization (TAI) terhadap prestasi belajar matematika ditinjau dari kreativitas belajar siswa. Tesis tidak dipublikasikan. Surakarta: UNS.

Zakaria, E. dan Iksan, Z. 2007. Promoting Cooperative Learning in Science and Mathematics Education: A Malaysian Perspective. Eurasia Journal of Mathematics, Science \& Technology Education, 3(1): 35-39. 